\title{
PATHOGEN OUTBREAKS REVEAL LARGE-SCALE EFFECTS OF COMPETITION IN STREAM COMMUNITIES
}

\author{
Steven L. KohleR ${ }^{1}$ And Michael J. WiLeY ${ }^{2}$ \\ ${ }^{1}$ Center for Aquatic Ecology, Illinois Natural History Survey, Champaign, Illinois 61820 USA \\ ${ }^{2}$ School of Natural Resources and Environment, The University of Michigan, Ann Arbor, Michigan 48109 USA
}

\begin{abstract}
The ability of small-scale experiments to predict dynamics and patterns observed at larger scales is an important issue in ecology. In this paper, we describe responses of benthic, trout stream communities to replicated, whole-ecosystem perturbations resulting from pathogen-induced reductions in populations of a dominant grazer, the caddisfly Glossosoma nigrior. Previous small-scale experiments suggested that Glossosoma had strong competitive effects on other grazers (through exploitation) and small-bodied filter-feeders (through interference). Glossosoma populations collapsed in a number of Michigan trout streams since the late 1980s and have been maintained at low levels by recurrent pathogen outbreaks. Here we address the effects on periphyton, grazers, and filterfeeders of parasite-induced Glossosoma reductions in six streams for which considerable pre- and post-collapse data are available, and we compare the results of this large-scale perturbation to responses predicted from a small-scale experiment that had been previously conducted in one of these streams. Periphyton and most grazers and filter-feeders showed marked increases in abundance following reduction in Glossosoma populations. Several grazers that were rare or absent prior to Glossosoma collapse have established sizable populations, suggesting that they had been excluded by competition with Glossosoma. The small-scale experiment successfully predicted the direction of response of most taxa to whole-stream reductions in Glossosoma abundance, but it tended to underestimate the extent and magnitude of Glossosoma's effects in the community. In these systems, observations at larger spatial and temporal scales have been essential to developing a clearer understanding of the mechanisms structuring communities.
\end{abstract}

Key words: competitive exclusion in streams; Cougourdella; filter-feeders; Glossosoma pathogens: grazers; microsporidian; periphyton; Trichoptera; whole-ecosystem perturbations.

\section{INTRODUCTION}

A central methodological problem in ecology concerns the extent to which experiments and observations conducted at relatively small spatial and temporal scales can be generalized to larger scales (Dayton and Tegner 1984, Wiens et al. 1986, Pimm 1991, Levin 1992). The vast majority of ecological experiments are conducted over time frames that are short relative to the lifetimes of organisms being studied and over spatial scales that are small relative to the areas used by the populations of interest (Connell 1983, Schoener 1983, Sih et al. 1985, Goldberg and Barton 1992, Gurevitch et al. 1992). While it is clear that the choice of scale at which experiments are conducted can greatly affect the interpretation of results (Brown et al. 1986, Tilman 1989, Wootton 1992, Lively et al. 1993), and that ecologists increasingly recognize the limitations of small-scale experiments, it is usually necessary to implicitly assume that the results of small-scale experiments can be generalized to larger scales (Neill 1994). Because it is seldom possible to conduct adequately replicated long-term experiments over large

Manuscript received 18 October 1996; accepted 18 December 1996. spatial scales (e.g., entire ecosystems), this assumption has rarely been tested.

There have been several attempts to compare the results of experiments conducted in the same system across differing spatial and temporal scales that include (Schindler et al. 1985, Carpenter and Kitchell 1988, Carignan and Planas 1994, Sarnelle 1997) or do not include (Gascon and Travis 1992, Ives et al. 1993) comparisons with results from whole-ecosystem manipulations. In these studies, manipulations at smaller scales were well replicated, but whole-ecosystem perturbations, if performed, were generally not replicated (but see Carignan and Planas 1994).

It is generally agreed that a powerful feature of whole-ecosystem experiments is their high level of realism. Effects of experimental scale and artifacts associated with the type and scale of manipulations (e.g., cage effects) should be minimized, especially if the manipulation is sufficiently long term and if processes operating at even larger scales are of relatively minor importance in affecting within-system structure and dynamics. Because adequate replication is seldom feasible, ecosystem experiments generally achieve increased realism at the expense of reductions in precision and statistical power to detect treatment effects. 
Lack of replication limits the extent to which even the results of large-scale experiments can be generalized (Frost et al. 1988).

In this paper, we describe results of a large-scale natural perturbation that has been occurring in stream systems in which similar small-scale experiments had been previously conducted. The large-scale perturbation has been created by outbreaks of a pathogen that has effectively removed a dominant competitor from entire ecosystems (Kohler and Wiley 1992).

Previous studies in stony-bottomed trout streams indicated that the bivoltine herbivorous caddisfly Glossosoma nigrior (Trichoptera: Glossosomatidae) is a particularly strong interactor (MacArthur 1972, Paine 1980) in their benthic communities (Wiley and Kohler 1981, McAuliffe 1984, Kohler 1992). Many grazers in these systems are food limited (Hart 1987, Hart and Robinson 1990, Kohler 1992), and Glossosoma maintains grazer food, i.e., periphyton, at very low levels throughout the year (Kohler 1992). Field experiments have shown that Glossosoma has strong competitive effects on most other grazers in the community (through exploitation; McAuliffe 1984, Kohler 1992) and on some relatively small-bodied filter-feeders (through a form of passive interference; Wiley and Kohler 1981, Kohler 1992). Because these experiments were conducted over relatively small spatial (i.e., within a stream reach) and temporal (days to months) scales, population-level responses of grazers to the exclusion of Glossosoma from habitats were not measured. Rather, these studies monitored the responses of individuals to local-scale variability in food abundance resulting from manipulations of Glossosoma density. Population- and community-level effects of Glossosoma were then inferred from such responses.

The collapse of Glossosoma populations in a number of Michigan trout streams was first observed in the late 1980s (Kohler and Wiley 1992). In all cases, dramatic reductions in Glossosoma density (e.g., Fig. 1A) have been associated with increased prevalence in the population of the microsporidian Cougourdella sp. (Microspora: Cougourdellidae) (Kohler and Wiley 1992). This pathogen is known to infect only Glossosoma (S. L. Kohler and M. J. Wiley, personal observation). In streams where Cougourdella epizootics have been observed, Glossosoma populations have been reduced by 4-40 fold and maintained at low levels by recurrent outbreaks of the parasite. Because of the paucity of long-term records, it is unclear whether such collapses have occurred in the past. Here we report on an analysis of the effects of parasite-induced Glossosoma reductions in six streams for which considerable pre- and postcollapse data are available. Our main objectives are to: (1) use replicated, large-scale perturbations to examine the system-wide effects of Glossosoma on periphyton abundance and invertebrate community structure, and (2) compare the results from these large-scale perturbations to responses predicted from an earlier
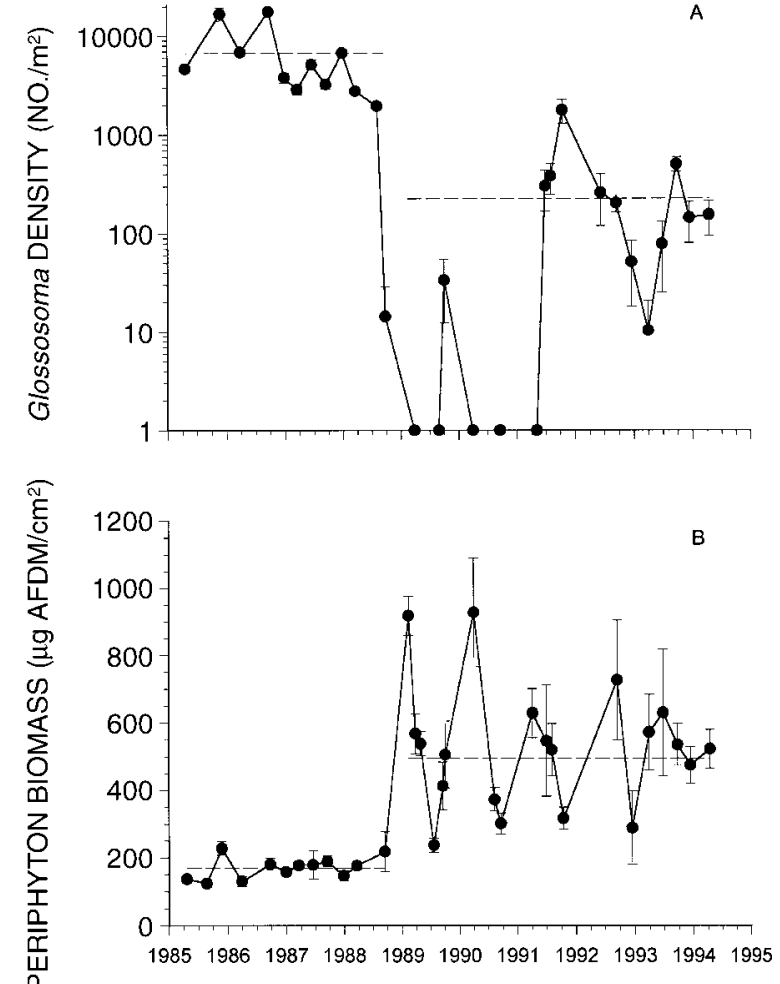

FIG. 1. Glossosoma nigrior (A) and periphyton biomass (B) in Spring Brook. Values are means \pm 1 SE $(N=5-10)$. Horizontal dashed lines are the overall mean density or biomass for the periods before and after Glossosoma's collapse in 1988.

small-scale experimental study (Kohler 1992) conducted at one of these same sites.

\section{Methods}

Although $>20$ streams in Michigan's lower peninsula are known to contain Glossosoma populations dramatically reduced by outbreaks of Cougourdella (M. J. Wiley and S. L. Kohler, personal observation), in this paper we restrict our analyses to 6 streams for which considerable data on their benthic communities were available both before and after the collapse of Glossosoma populations (Table 1). The streams are similar, and representative of many stony-bottomed coldwater streams in the Great Lakes region, in that they: (1) support trout populations (generally brown and/or brook trout), (2) receive extensive groundwater inputs and, consequently, have highly stable flow regimes (see Poff and Ward 1989, Wiley et al. 1997), (3) drain wetlands and woodlands with little urban or agricultural development, and (4) have riffle and run substrates largely consisting of gravels and cobbles over sand. The streams are from four different drainage basins, with northern and southern streams separated by $>300 \mathrm{~km}$. Although they share many characteristics, these streams vary appreciably in size, thermal regime, 
TABLE 1. Characteristics of the six streams that were studied before and after the collapse of their Glossosoma populations. All of the streams support trout populations and have very stable flow regimes.

\begin{tabular}{|c|c|c|c|c|c|}
\hline Stream & $\begin{array}{c}\text { Drainage } \\
\text { basin }\end{array}$ & $\begin{array}{c}\text { Drainage } \\
\text { area } \\
\left(\mathrm{km}^{2}\right)\end{array}$ & $\begin{array}{l}\text { Stream } \\
\text { order }\end{array}$ & $\begin{array}{l}\text { Maximum } \\
\text { summer } \\
\text { tempera- } \\
\text { ture } \\
\left({ }^{\circ} \mathrm{C}\right)\end{array}$ & $\begin{array}{l}\text { Piscivores } \\
\text { present }\end{array}$ \\
\hline \multicolumn{6}{|l|}{ Southwest Michigan } \\
\hline Spring Brook & Kalamazoo R. & 80 & 2 & $20^{\circ}$ & Yes \\
\hline Seven Mile Creek & Kalamazoo R. & 36 & 2 & $22^{\circ}$ & Yes \\
\hline Silver Creek & Kalamazoo R. & 26 & 2 & $24^{\circ}$ & Yes \\
\hline \multicolumn{6}{|l|}{ Northern Michigan } \\
\hline Hunt Creek & Thunder Bay R. & 62 & 2 & $20^{\circ}$ & No \\
\hline Irontone Creek & Cheboygan R. & 10 & 1 & $18^{\circ}$ & No \\
\hline Roaring Brook & Lake Michigan $\dagger$ & 21 & 2 & $18^{\circ}$ & Some years \\
\hline
\end{tabular}

and food web structure (e.g., the presence of piscivorous fish) (Table 1). Therefore, our results should be applicable to a broad class of hydrologically stable streams in which Glossosoma is a strong interactor.

The three streams in southwest Michigan are within the same drainage basin, but they are separated by at least $20 \mathrm{~km}$, and the mainstem river, the Kalamazoo River, is too warm to support populations of most of the taxa found in its coldwater tributaries. Therefore, we assume that these streams function largely as independent systems.

In our study streams, Glossosoma and most invertebrates with which it is commonly found occur largely on hard substrates over a broad range in current velocity and water depth (Kovalak 1978a,b). Glossosoma occurs in suitable habitats throughout the length of these streams, and the entire population in each stream and its immediate tributaries has been affected by $\mathrm{Cou}$ gourdella outbreaks (S. L. Kohler and M. J. Wiley, personal observation). Therefore, effects of Glossosoma reduction on components of the hard substrate community should be system-wide.
The abundance of invertebrates and periphyton on hard substrates was estimated from samples of individual rocks (generally $50-80 \mathrm{~cm}^{2}$ projected top surface area), individual concrete tiles $\left(100 \mathrm{~cm}^{2}\right.$ top area), or clusters of five contiguous rocks $\left(70-120 \mathrm{~cm}^{2}\right.$ total top area). Substrates were carefully lifted from the stream bottom with a $230-\mu \mathrm{m}$ mesh net held immediately downstream to capture any dislodged animals, and the substrate and net contents were preserved in $4 \%$ buffered formalin. Generally 4-10 samples were arbitrarily taken from a riffle/run area on each sampling date (Table 2). On each sampling date, we attempted to take samples from a broad range of current velocity. We have assumed that the sites sampled are representative of stony-bottomed areas throughout these streams.

Streams were sampled on multiple dates before and after the collapse of Glossosoma populations (Table 2). Although samples were taken throughout the year in most streams, in this paper we focus on samples taken in late winter-early spring and late summer. Such samples are useful for characterizing the population dy-

TABLE 2. Time periods for each stream during which Glossosoma population density was either high or low (due to Cougourdella epizootics). For each period, the number of dates in late winter-early spring and late summer on which benthic samples were taken, and the number of samples taken, are given.

\begin{tabular}{|c|c|c|c|c|c|c|c|c|}
\hline \multirow[b]{3}{*}{ Stream } & \multicolumn{4}{|c|}{ High Glossosoma density } & \multicolumn{4}{|c|}{ Low Glossosoma density } \\
\hline & \multirow[b]{2}{*}{ Years } & \multirow{2}{*}{$\begin{array}{l}\text { No. } \\
\text { sam- } \\
\text { pling } \\
\text { dates }\end{array}$} & \multicolumn{2}{|c|}{$\begin{array}{l}\text { Samples per } \\
\text { date }\end{array}$} & \multirow[b]{2}{*}{ Years } & \multirow{2}{*}{$\begin{array}{l}\text { No. } \\
\text { sam- } \\
\text { pling } \\
\text { dates }\end{array}$} & \multicolumn{2}{|c|}{$\begin{array}{l}\text { Samples per } \\
\text { date }\end{array}$} \\
\hline & & & Mean & Range & & & Mean & Range \\
\hline \multicolumn{9}{|l|}{ Southwest Michigan } \\
\hline Spring Brook & $1985-1988$ & 9 & 7.4 & $5-10$ & 1989-1994 & 15 & 6.4 & $5-10$ \\
\hline Seven Mile Creek & 1986-1990 & 9 & 5.1 & $5-6$ & 1991-1994 & 9 & 6.0 & $5-8$ \\
\hline Silver Creek & 1988-1991 & 8 & 5.6 & $5-10$ & 1992-1994 & 6 & 7.0 & $5-8$ \\
\hline \multicolumn{9}{|l|}{ Northern Michigan } \\
\hline Hunt Creek & 1977-1985, 1992-1994 & 19 & 4.8 & $4-5$ & 1988-1991 & 20 & 6.4 & $4-10$ \\
\hline Irontone Creek & $1990-1992$ & 6 & 6.5 & $4-10$ & 1993-1994 & 8 & 4.2 & $3-5$ \\
\hline Roaring Brook & 1991,1993 & 2 & 7.5 & $5-10$ & 1994-1995 & 2 & 4.5 & $4-5$ \\
\hline
\end{tabular}


namics of three groups of invertebrates that, collectively, comprise most of the species we encounter: (1) univoltine species in which larvae developed during the fall and winter and emerged in late winter-early spring, (2) taxa in which larvae developed during the summer and emerged in late summer, and (3) bivoltine species having late winter-early spring and late summer emergences. A fourth, relatively small group of species had emergences during the winter or summer (e.g., Diamesa, Drunella lata), and their population sizes could not be adequately estimated by our early spring and late summer samples. Consequently, these taxa could not be included in the analyses reported here, although they were considered in the small-scale experiment.

In the laboratory, periphyton was removed with a toothbrush from known areas of the top surface of stones or tiles. Periphyton biomass was quantified as ash-free dry mass (AFDM) and as cell density (cells per square centimeter). For AFDM determinations, a subsample of material scraped from the top surface of substrates was filtered onto a precombusted $\left(500^{\circ} \mathrm{C}\right)$ glass fiber filter (Whatman $\mathrm{GF} / \mathrm{F}$ ), dried at $60^{\circ} \mathrm{C}$, weighed to the nearest microgram on a Cahn microbalance, combusted, and reweighed. For cell density determinations, a subsample was filtered onto a membrane filter and cleared with immersion oil. Cell densities were determined from the transect length and width required to count 300 cells at $400 \times$.

Following removal of periphyton samples, all substrates in a sample were thoroughly scrubbed to remove all invertebrates, and sample contents were concentrated in a $120-\mu \mathrm{m}$ mesh sieve. For most taxa, samples were sorted in their entirety using a dissecting microscope at $10 \times$. Occasionally, densities of very abundant taxa (e.g., Hydropsyche) were estimated from subsamples.

We expressed invertebrate density as the number of individuals per square meter of projected top surface. Projected top surface area of rocks was estimated using a computerized video measurement system. Although this approach underestimates actual substrate area, it is analogous to substrate area measures obtained when standard benthos sampling devices (e.g., Surber and Hess samplers) are employed.

We tested for differences in periphyton and invertebrate densities prior to and following collapse of Glossosoma populations using one-way analysis of variance, blocking by stream, of log-transformed (periphyton) or $\log (X+1)$-transformed (invertebrates) values. This test is equivalent to a $t$ test for paired comparisons, with streams being the units of replication. We used one-tailed tests of significance because, based on the results of the small-scale experiments, we expected abundances of periphyton, grazers, and filterfeeders to increase or remain unchanged following Glossosoma collapse. For each stream, the precollapse value was the mean of the mean values from each of the precollapse sampling dates. Postcollapse values were obtained similarly. Sampling dates within a year that were used to determine pre- and postcollapse mean density in each stream varied among species, depending upon their life cycles as discussed above. Where possible, we used only sampling dates that fell immediately prior to the completion of a generation, as such samples should best reflect long-term trends in population abundance. For example, we used samples taken in late winter-early spring for univoltine species having early spring emergences.

Invertebrate taxa included in these analyses were the periphyton-grazers and filter-feeders considered in Kohler (1992), with the exception of the Chironomidae and several taxa that have established sizeable populations in some streams following reductions in Glossosoma abundance. Because of differences in species present among streams, it was necessary to perform these analyses at the genus or, in some cases, family level.

\section{Comparison of small- and large-scale perturbations}

The results of an experiment in which Glossosoma abundance on habitats in Spring Brook was manipulated over a 10-mo period in 1986-1987 has been described in detail elsewhere (Kohler 1992). A similar experiment, with similar results, was reported by McAuliffe (1984). Briefly, the experiment involved two treatments in a randomized block design: a Glossosoma exclusion in which Glossosoma was prevented from colonizing substrates (concrete tiles with $100 \mathrm{~cm}^{2}$ top surface area), and a control in which substrates could be colonized by Glossosoma. The movements of most other invertebrates were not restricted by these treatments. Cages were not used in either treatment, so artifacts associated with their use could be avoided. The experiment was sampled nine times between December 1986 and September 1987, which spanned two Glossosoma generations. Response variables were the abundances of periphyton and invertebrates and the size distributions of some relatively sessile chironomids. The latter were used to test for differences in individual growth rate between the treatments.

We used two approaches to compare the results of this small-scale experiment with the patterns observed in the larger scale perturbation established by pathogen-induced, whole-stream reductions in Glossosoma populations. First, we considered whether the smallscale experiment correctly predicted responses of periphyton, grazers, and filter-feeders to the pathogeninduced reductions in Glossosoma within Spring Brook. For each taxon, we followed an approach described by Sarnelle (1997) to quantify the magnitude of Glossosoma's effect in the small-scale experiment as: effect size $=-\ln \left[\left(N_{\text {control }}+1\right) /\left(N_{\text {exclusion }}+1\right)\right]$, where $N_{\text {control }}$ and $N_{\text {exclusion }}$ are the mean densities of a taxon in the control and Glossosoma exclusion treatments, respectively, on a sampling date. Effect size was aver- 
aged over all sampling dates included in the repeated measures analysis of variance (see Kohler 1992) to obtain a mean value for each taxon. Similarly, the magnitude of Glossosoma's effect on other taxa in the whole-stream perturbation was quantified as: effect size $=-\ln \left[\left(N_{\text {high }}+1\right) /\left(N_{\text {low }}+1\right)\right]$, where $N_{\text {high }}$ is the mean density during the period 1985-1988 prior to pathogen outbreaks when Glossosoma population density was high, and $N_{\text {low }}$ is the mean density during the period 1989-1994 when recurrent pathogen outbreaks maintained Glossosoma at low density (see Fig. 1). Positive effect size values indicate that a taxon increased in abundance when Glossosoma abundance was reduced. For example, the data in Fig. 1B yield an effect size of 0.97 for periphyton AFDM in Spring Brook, which corresponds to a 2.9-fold increase following Glossosoma collapse.

If the small-scale experiment correctly predicted the direction and magnitude of effects observed in the large-scale manipulation within Spring Brook, then small-scale and large-scale effect sizes should be positively correlated with a slope of 1 . We used linear regression to test this prediction. We also considered whether the small-scale experiment correctly predicted only the direction of Glossosoma effects. We placed all taxa into one of two categories: those that increased in abundance, and those that decreased or showed no change in abundance with reductions in Glossosoma density. For the small-scale experiment, we used results of repeated-measures analyses of variance to categorize the responses of taxa (see Kohler 1992). For the largescale manipulation, we considered a taxon to have increased in abundance with reductions in Glossosoma density if effect size was $\geq 0.5$. This value is conservative, as one species was significantly more abundant in the Glossosoma exclusion treatment than in the control in the small-scale experiment but had a mean effect size value $<0.5$. We used a $G$ test with Williams' correction (Sokal and Rohlf 1981) to determine whether the proportion of taxa in these two categories differed between the small- and large-scale manipulations.

We also examined whether the small-scale experiment in Spring Brook correctly predicted Glossosoma's effect on periphyton and primary consumers in the set of six streams affected by pathogen outbreaks. Largescale effect size for each taxon and stream was quantified as described above for Spring Brook. We used one-way analysis of variance, blocking by taxon, to test for differences in effect size between the smallscale and large-scale perturbations.

\section{RESUlts}

\section{Patterns in the whole-stream perturbations}

During Cougourdella outbreaks, Glossosoma population density was markedly reduced in each of the streams (Fig. 2) $\left(F_{1,5}=99.93, P<0.001\right)$. The magnitude of Cougourdella's effect on Glossosoma in each

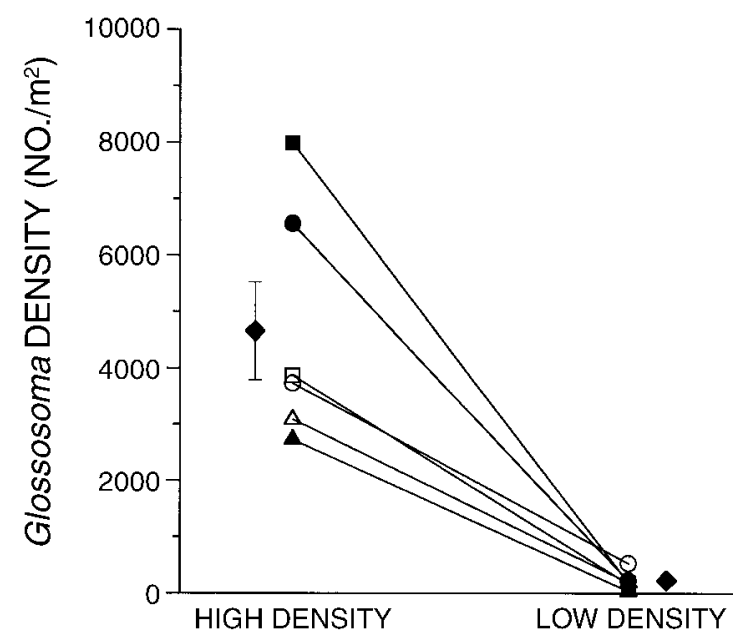

FIG. 2. Mean abundance of Glossosoma nigrior in six streams from southwest and northern lower Michigan during periods prior to pathogen outbreaks (=high density) and during recurrent pathogen outbreaks (=low density). Lines connect data points for individual streams; each point represents the mean value calculated for sampling dates before or after the collapse of Glossosoma. The point with an error bar $( \pm 1$ $\mathrm{SE})$ is the overall mean. Symbols for the streams are: $\bigcirc$ Hunt Creek, $\square$ Irontone Creek, $\triangle$ Roaring Brook, Spring Brook, - Seven Mile Creek, $\boldsymbol{\Delta}$ Silver Creek.

stream can be quantified as $-\ln$ (mean Glossosoma abundance prior to collapse $\div$ mean Glossosoma abundance during pathogen outbreaks). These effect size values ranged from -1.96 to -4.22 , with a mean value of $-3.21 \pm 0.8$ (mean $\pm 1 \mathrm{SE}$ ), which corresponds to, on average, a nearly 25-fold reduction in Glossosoma density during Cougourdella epizootics.

Parasite-induced reductions in Glossosoma population density consistently resulted in an increase in Glossosoma's food resource, periphyton, and stabilization of periphyton biomass at levels significantly greater than pre-collapse levels (Figs. 1B, and 3a; Table 3). Periphyton communities were dominated by diatoms both before and after removal of Glossosoma, although short-term dominance by filamentous or other macroalgae, especially Batrachospermum, has been observed when Glossosoma collapse took place in winter. Because areal periphyton production is positively correlated with periphyton biomass in our systems (Hart et al. 1991; S. L. Kohler, personal observation), collapse of Glossosoma populations also likely resulted in an increase in primary production.

All of the grazers and filter-feeders considered in this analysis increased in population density, typically $2-5$ fold, in most streams following reductions in Glossosoma density (Fig. 3). Most periphyton grazers responded to the collapse of Glossosoma with significant increases in population size (Table 3 ). Three taxa that did not respond consistently across sites (i.e., the mayfly Ephemerella, the caddisfly Micrasema, and the riffle 

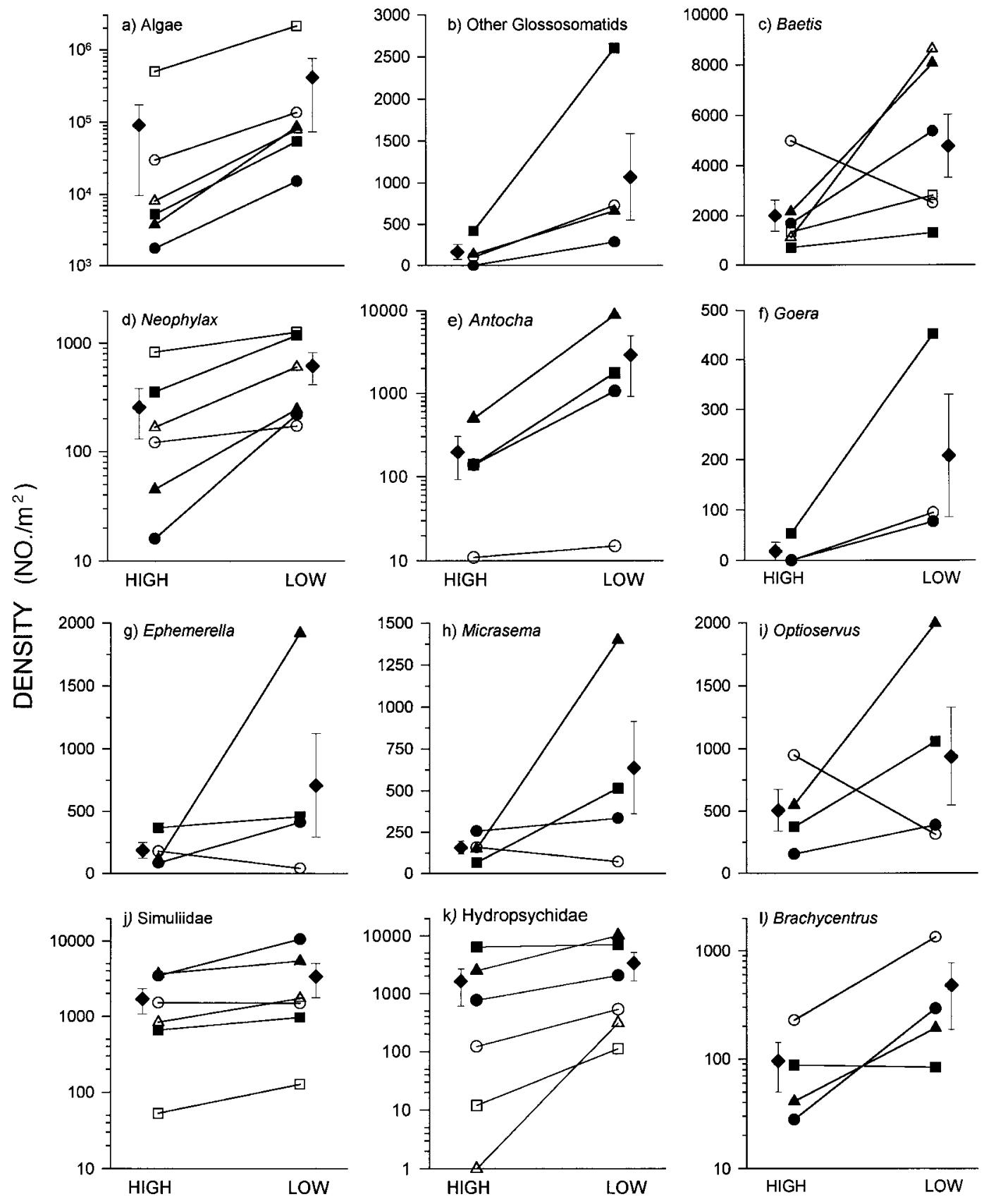

\section{Glossosoma DENSITY}

FIG. 3. Mean abundances of (a) periphyton (as algal cells $\left./ \mathrm{cm}^{2}\right),(\mathrm{b}-\mathrm{i})$ periphyton-grazing insects, and (j-l) filter-feeders as a function of Glossosoma density (high, low = prior to or during recurrent pathogen outbreaks, respectively) in six streams from southwest and northern lower Michigan. Invertebrate densities are expressed as individuals $/ \mathrm{m}^{2}$. Symbols are as in Fig. 2.

beetle Optioservus) showed striking increases in a few streams (Fig. 3).

Because our data for macroinvertebrates often span several generations before and after Glossosoma collapse, these observed changes in macroinvertebrate density represent population-level responses, not the aggregative responses of individuals to increased re- source availability observed in previous small-scale studies (McAuliffe 1984, Kohler 1992). Among the most striking responses of grazers have been dramatic increases in population sizes of several species that had been extremely rare or absent prior to the collapse of Glossosoma populations (Figs. 3 and 4; e.g., Goera stylata and Protoptila tenebrosa in Hunt Creek, Aga- 

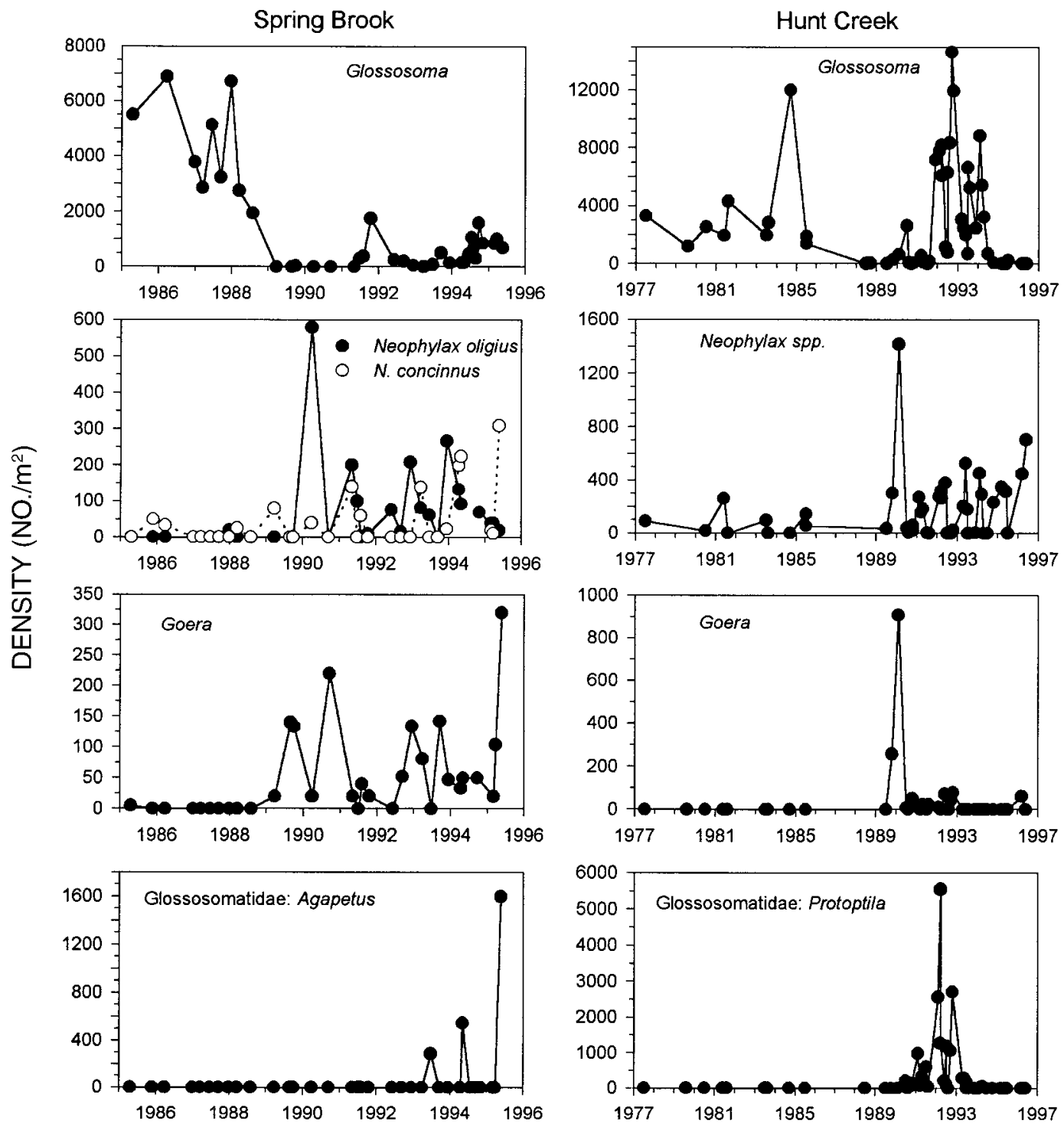

FIG. 4. Temporal changes in the abundance of Glossosoma and other herbivorous caddisflies in three streams. Error bars are omitted for clarity. All sampling dates are shown, and therefore the plots illustrate within- and between-generation dynamics. All of the species are univoltine except Glossosoma, which is bivoltine.

petus hessi and Neophylax oligius in Spring Brook). Also note that several taxa responded to Glossosoma's decline with a lag of one or more years (Fig. 4). In Hunt Creek, the recovery of Glossosoma during 19921994 has been associated with a decrease in the density of Goera and, more recently, Protoptila (Fig. 4).

\section{Comparison of small- and large-scale perturbations: Spring Brook}

We first consider how well the small-scale experiment, which was conducted in Spring Brook, predicted effects of the stream-wide reductions in Glossosoma in Spring Brook that resulted from Cougourdella epizootics. Kohler (1992) analyzed responses of 20 taxa (periphyton, grazers, and filter-feeders) to the
Glossosoma treatments in the small-scale experiment. Because of their life histories, insufficient data were available for three of these taxa for the large-scale perturbation. Of the remaining 17 taxa, 15 increased in abundance following Glossosoma's collapse, which agrees well with expectations based on the results of the small-scale experiment, in which 12 taxa were significantly more abundant in the Glossosoma exclusion than in the control $\left(G_{\text {adj }}=2.98, P>0.05\right)$. However, the magnitude of Glossosoma's effects in the large-scale perturbation was poorly predicted by the small-scale experiment (Fig. 5). The slope of the regression of large-scale on small-scale effect size was not significantly different from 0 (slope $=-0.06, t_{15}$ $=-0.25, P=0.807)$. Two factors appeared to con- 

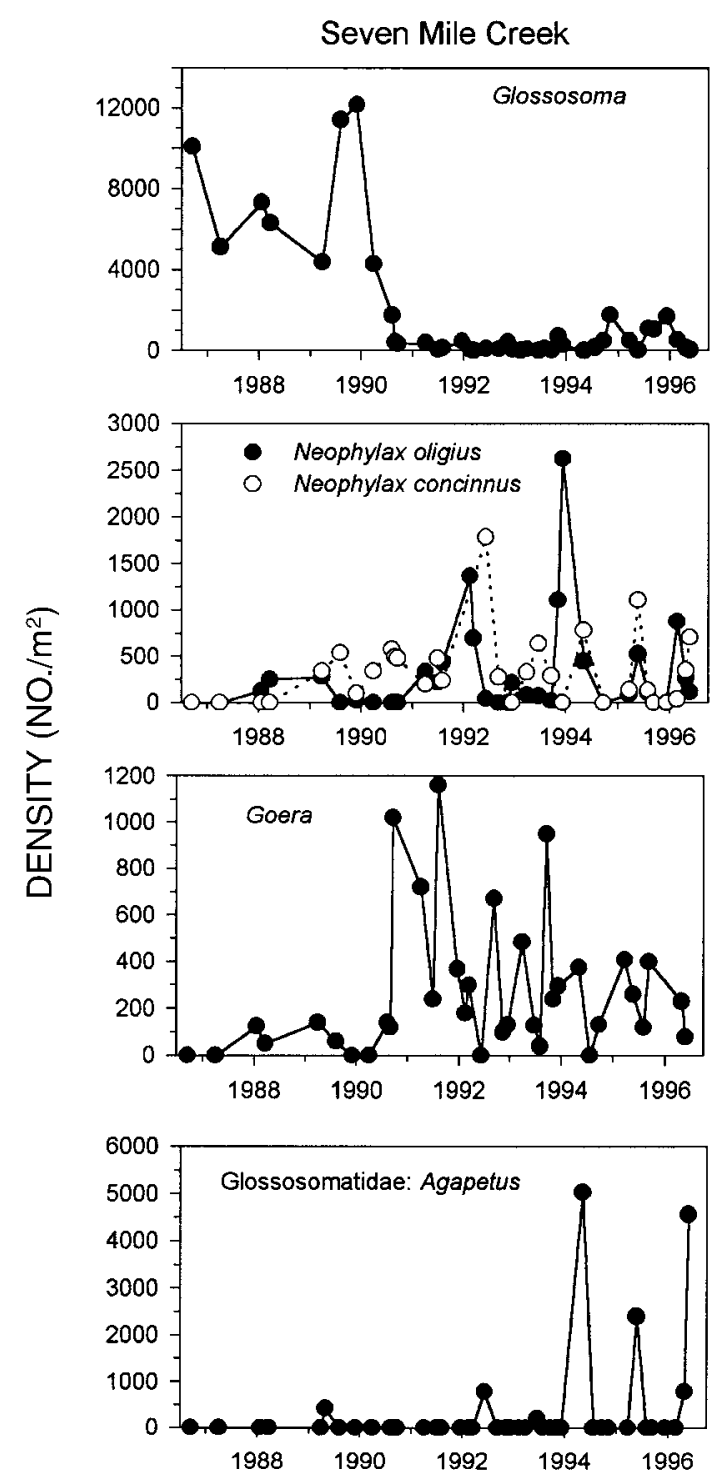

Fig. 4. Continued.

tribute to this pattern. First, in many cases, the smallscale experiment underestimated the magnitude of Glossosoma's effects observed in the large-scale perturbation (Fig. 5). Thirteen of 17 points are above the line of one-to-one correspondence between small- and large-scale effect size. Second, some taxa that were not strongly affected by the Glossosoma treatments in the small-scale experiment (e.g., Brachycentrus, Pagastia, Optioservus, Eukiefferiella) increased markedly in abundance following pathogen-induced collapse of Glossosoma (Fig. 5). For at least one of these taxa, Eukiefferiella, comparison of the magnitude of Glossosoma's effects using only population density as a response variable may be misleading. In the small-scale experiment, Eukiefferiella density was not significantly affected by the Glossosoma treat- ments, but individual growth rate was significantly greater in the Glossosoma exclusion (Kohler 1992).

Several taxa that increased markedly in abundance in Spring Brook following Glossosoma collapse could not be included in our analysis of large-scale vs. smallscale effects. These species, Neophylax oligius, N. concinnus, Goera stylata, and the glossosomatid Agapetus hessi, are all periphyton-grazing, case-building caddisflies. Estimates of large-scale effect size exceeded 2.25 for each of these species. At the time of the smallscale experiment (1986-1987), densities of these taxa in Spring Brook were below the limits of detection (Fig. 4). Furthermore, Glossosoma's effects on them could not have been assessed in the small-scale experiment because the treatment (elevation of substrates) that excluded Glossosoma would have also excluded these species, even if they had been present at higher densities.

\section{Comparison of small- and large-scale perturbations: all streams}

The strength of the Glossosoma treatments in the small-scale experiment can be quantified as $-\ln$ (mean Glossosoma abundance in the control treatment $\div$ mean Glossosoma abundance in the Glossosoma exclusion). This value, averaged over the nine sampling dates, equaled $-3.66 \pm 0.28$ (mean $\pm 1 \mathrm{SE}$ ), which is very similar to the strength of Cougourdella's effects on Glossosoma observed in the large-scale perturbations (i.e., mean effect size $=-3.21$ ). Therefore, the magnitude of the Glossosoma manipulations were comparable in the small-scale experiment and large-scale perturbations.

Fewer taxa were available for this comparison, as data were not available from all streams for the seven chironomid species considered above and in Kohler (1992). Also, it was necessary to pool results for the two Ephemerella species, leaving nine taxa that could be considered (i.e., those listed in Table 3 except Goera, Neophylax, and other glossosomatids). Based on results of the small-scale experiment, five of these were predicted to increase in abundance in the large-scale perturbations and six showed significant increases in density following Glossosoma collapses (Table 3). However, two filter-feeders, Brachycentrus and Hydropsychidae, were not predicted to increase but increased significantly in abundance, and one grazer, Ephemerella, exhibited the opposite pattern. Therefore, the responses of six of nine taxa were in the same direction predicted by the small-scale experiment.

The magnitude of Glossosoma's effects in the largescale perturbations was poorly predicted by the smallscale experiment (Fig. 6; scale effect in one-way ANOVA blocking by taxon: $F_{1,8}=3.63, P=0.029$ ). If only effects on algae and grazers are considered, the effect of experimental scale was not significant $\left(F_{1,5}=1.99\right.$, $P=0.116)$, suggesting that differential responses of filter-feeders in the small- and large-scale perturbations 
TABLE 3. Summary of $F$ values and their levels of statistical significance $(P)$ from analyses of variance of mean population densities during periods of high and low Glossosoma density. Stream was a blocking factor in the analyses.

\begin{tabular}{|c|c|c|c|c|c|}
\hline \multirow[b]{3}{*}{ Taxon } & \multirow{3}{*}{$\begin{array}{c}\begin{array}{c}\text { Number } \\
\text { of } \\
\text { streams }\end{array} \\
\end{array}$} & \multicolumn{4}{|c|}{ Source of variation } \\
\hline & & \multicolumn{2}{|c|}{ Stream } & \multicolumn{2}{|c|}{ Glossosoma } \\
\hline & & $F$ & $P$ & $F$ & $P$ \\
\hline Algae & 6 & 34.42 & $<0.001$ & 71.84 & $<0.001$ \\
\hline \multicolumn{6}{|l|}{ Grazers } \\
\hline Baetis & 6 & 1.37 & 0.368 & 5.34 & 0.034 \\
\hline Ephemerella & 4 & 0.72 & 0.602 & 0.76 & 0.224 \\
\hline Micrasema & 4 & 0.92 & 0.525 & 2.32 & 0.113 \\
\hline Optioservus & 4 & 1.19 & 0.445 & 0.93 & 0.203 \\
\hline Antocha & 4 & 13.72 & 0.029 & 11.30 & 0.022 \\
\hline Goera & 3 & 6.13 & 0.140 & 23.14 & 0.020 \\
\hline Neophylax & 6 & 7.01 & 0.026 & 13.74 & 0.007 \\
\hline $\begin{array}{l}\text { Other glossosomatids } \\
\quad \text { (Agapetus, Protoptila) }\end{array}$ & 4 & 3.21 & 0.182 & 7.99 & 0.033 \\
\hline \multicolumn{6}{|l|}{ Filter-feeders } \\
\hline Simuliidae & 6 & 55.91 & $<0.001$ & 12.22 & 0.009 \\
\hline Hydropsychidae & 6 & 6.46 & 0.031 & 6.08 & 0.028 \\
\hline Brachycentrus & 4 & 3.24 & 0.180 & 7.54 & 0.035 \\
\hline
\end{tabular}

Note: $P$ values are one-tailed for tests of Glossosoma effects and two-tailed for tests of stream effects. For Stream and Error terms in the model, df $=$ (number of streams) -1 ; for the Glossosoma term $\mathrm{df}=1$. Data are shown in Fig. 3 .

(Fig. 6) are largely responsible for poor prediction of the magnitude of large-scale effects by the small-scale experiment. However, as with comparisons made within Spring Brook, this analysis does not included responses of Goera, Neophylax, and other glossosomatids (Agapetus and Protoptila), which had mean largescale effect size values of $3.81 \pm 0.84,1.26 \pm 0.34$, and $2.75 \pm 0.97$, respectively.

\section{Discussion}

Our results indicate that periphyton and invertebrate grazers and filter-feeders in stony-bottomed trout streams are strongly affected by interactions with the herbivorous caddisfly Glossosoma nigrior. Massive, system-wide reductions in Glossosoma populations from recurrent pathogen outbreaks in several streams have consistently resulted in large increases in periphyton abundance and in population sizes of most grazers and filter-feeders. Among the grazing invertebrates, several taxa that were rare or absent prior to the collapse of Glossosoma populations have become prominent members of the benthic community. Collectively, these results provide compelling evidence for the importance of competition in affecting both the composition of benthic communities and population dynamics of individual taxa in these coldwater streams.

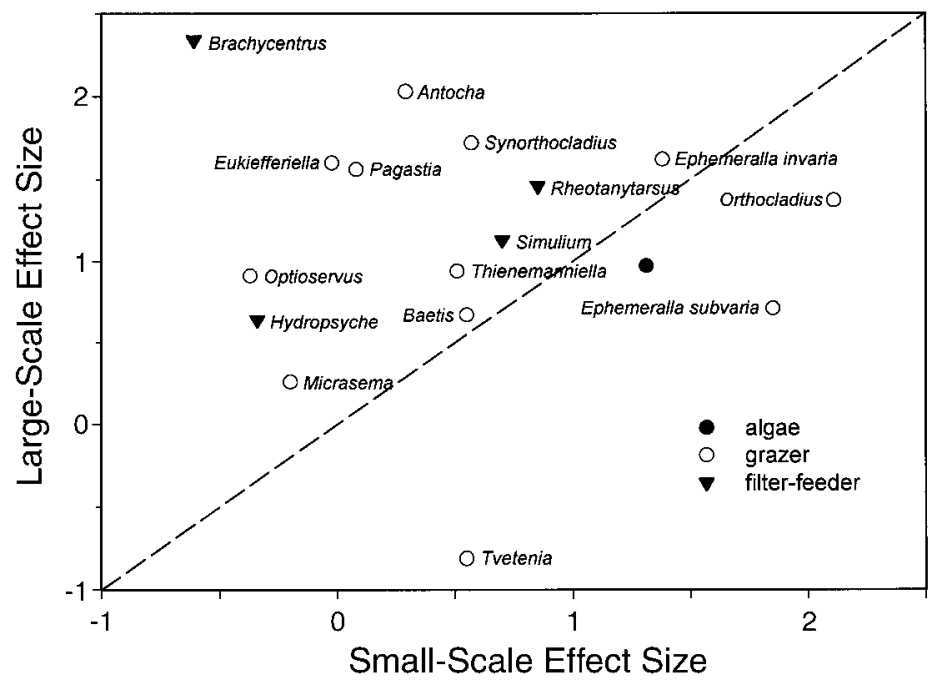

FIG. 5. Effects of small- and large-scale manipulations of Glossosoma abundance in Spring Brook on abundances of algae, grazers, and filter-feeders. Small-scale effect size is the mean response observed in the 10-mo experiment described in Kohler (1992). Effect size = $-\ln \left[\left(N_{\text {control }}+1\right) /\left(N_{\text {exclusion }}+1\right)\right]$, where $N_{\text {control }}$ and $N_{\text {exclusion }}$ are the densities in the control and Glossosoma exclusion treatments, respectively. Large-scale effect size is a measure of the response to the stream-wide reduction in Glossosoma population density by pathogen outbreaks. Effect size $=-\ln \left[\left(N_{\text {high }}+1\right) /\left(N_{\text {low }}+\right.\right.$ 1)], where $N_{\text {high }}$ is the mean density during the period (1985-1988) prior to pathogen outbreaks when Glossosoma population density was high, and $N_{\text {low }}$ is the mean density during the period (1989-1994) when recurrent pathogen outbreaks maintained Glossosoma at low density. Effect size for algae is based on AFDM. The dashed line denotes a one-to-one correspondence between small- and large-scale effect size. 
FIG. 6. Comparison of the effects on algae, grazers, and filter-feeders of small-scale manipulations of Glossosoma abundance in Spring Brook with large-scale (i.e., whole-stream) changes in Glossosoma density resulting from pathogen outbreaks in six streams. Small-scale effect size is as described in the legend of Fig. 2. For a given taxon, large-scale effect size was calculated for each stream in which the taxon was present as $-\ln \left[\left(N_{\text {high }}+1\right) /\left(N_{\text {low }}+1\right)\right]$, where $N_{\text {high }}$ is the mean density prior to pathogen outbreaks when Glossosoma population density was high, and $N_{\text {low }}$ is the mean density when recurrent pathogen outbreaks maintained Glossosoma at low density. Values shown are the means over all streams in which the taxon was present.

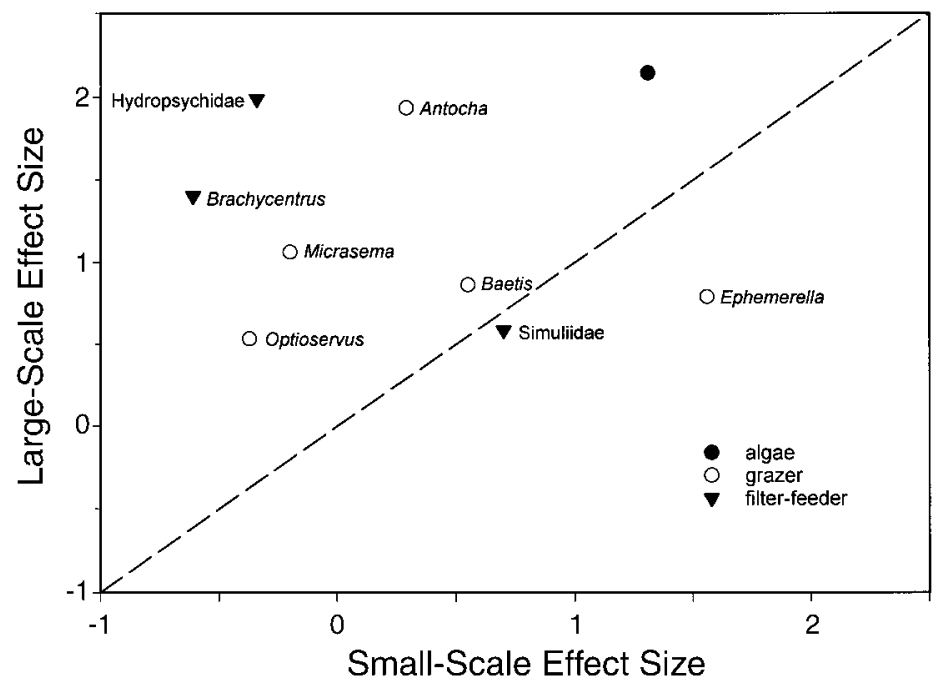

Because the manipulations of Glossosoma abundance in both the small-scale and large-scale experiments were performed within the context of the entire food web, the numerical responses of algae and invertebrates to reductions in Glossosoma density estimate the net effect of Glossosoma on these taxa (Lawlor 1979). This net effect is the sum of the "direct" effect of competition with Glossosoma (actually an indirect effect for interactions with other grazers, as the mechanism of competition is largely exploitation [McAuliffe 1984, Kohler 1992]) and any indirect effects mediated by Glossosoma's presence in the food web. Such indirect effects are likely to have been less important in the short-term experiments than in the longer term, pathogen-induced manipulation (Bender et al. 1984, Brown et al. 1986, Tilman 1989, Wootton 1992, Lively et al. 1993), which makes direct comparison of smalland large-scale manipulations difficult. Other factors could also affect the outcome of otherwise identical experiments conducted at different scales. For example, changes in the spatial scale of manipulations can result in changes in factors (e.g., spatial heterogeneity) other than the size of experimental units, resulting in species responding differently to manipulations performed at different scales (Frost et al. 1988, Cooper et al., in press). Further, differences among streams in the structure of their food webs (e.g., Table 1) could result in differences among streams in the responses of primary consumers to changes in Glossosoma abundance (Leibold and Wilbur 1992, Wootton 1994).

The differential responses of relatively large-bodied filter-feeders (Hydropsychidae, Brachycentrus) in the small-scale experiment and large-scale perturbations (Fig. 6) illustrate difficulties with predicting responses at larger scales based on the results of small-scale experiments. Glossosoma affects the local abundances of some small-bodied filter-feeders (e.g., Simuliidae) through a form of passive interference competition
(Wiley and Kohler 1981, Kohler 1992), but such interactions have not been observed with large-bodied taxa. Because seston concentrations probably increased (Peterson et al. 1985) with increases in periphyton biomass in streams where Glossosoma was reduced, increases in hydropsychid and Brachycentrus densities may be mediated, in part, by the indirect effects of Glossosoma on their food supply. Because such a process operates at a relatively large spatial scale, indirect effects of this kind could not have been detected in the small-scale experiment.

For the remaining taxa (largely algae and grazers), there was very good agreement between the results of the small- and large-scale manipulations in terms of the directions of responses. With few exceptions, taxa that increased in abundance during the small-scale experiment also increased following system-wide reductions in Glossosoma. The main difference between the results of the small- and large-scale perturbations was in the magnitude of Glossosoma's effects on periphyton and other grazers, which often was underestimated by the small-scale experiment (e.g., Figs. 5 and 6). The strongest evidence that the small-scale experiment underestimated the strength of interactions in the community is that it provided no indication that important grazers such as Goera stylata, Neophylax oligius, Protoptila, and Agapetus had been effectively excluded from the community. Thus, although the results of the small-scale experiment and the whole-stream perturbations were largely congruent regarding Glossosoma's effects on periphyton and grazers, observations at larger scales were necessary to accurately assess the magnitude and extent (i.e., the number of species affected) of Glossosoma's effects, and to suggest previously undocumented mechanisms (e.g., indirect effects of Glossosoma on food for filter-feeders) by which Glossosoma affects benthic community structure.

The quantitative differences between the results of 
the small- and large-scale manipulations illustrate limitations of the small-scale study in terms of both the spatial and temporal extent of the manipulations. For example, when species are strongly suppressed by competitors or predators, it is unlikely that they can respond to local (patch-scale) releases from competition or predation because their ability to recruit into those patches is restricted by ongoing interactions at a larger spatial scale (see Englund and Olsson 1996). Even when species are able to respond to the removal of a strong competitor (i.e., by increasing the spatial scale of the manipulation), there may be appreciable time lags in response arising from both the rarity or absence of the species in the community at the time of competitor removal, and life history characteristics of the species. Finally, as discussed above regarding the differential responses of large-bodied filter-feeders, the operation of some processes may not be detectable in manipulations performed over relatively small spatial or temporal scales (Frost et al. 1988).

These mechanisms describe several ways in which the strength of interactions in a community may be underestimated by small-scale experiments, as has been observed in this study. However, there are also a variety of ways by which small-scale studies may accentuate the operation of processes in a community and, consequently, overestimate the strength of species interactions. For example, if interactions requiring contact between individuals (e.g., interference competition, predation) are particularly important, their strength may be exaggerated in experiments conducted over small spatial scales if the spatial overlap between populations increases with decreasing spatial scale (Williamson 1993). Sarnelle (1997) studied a system in which such contact-mediated interactions were expected to be important and found that patterns and dynamics observed at the whole-ecosystem scale were well predicted by the results of relatively long-term experiments conducted in large enclosures but not by short-term experiments conducted in small enclosures. The ability of small-scale experiments to predict responses observed at larger scales may depend on their scale and on the relative importance of various processes operating in the community.

Therefore, the main conclusions of the small-scale experiment, that Glossosoma strongly depresses the abundance of periphyton and, consequently, has strong negative effects, through exploitation competition, on most other periphyton-grazers, were strongly supported by the large-scale perturbations. Responses of smallbodied filter-feeders (e.g., Simulium, Rheotanytarsus) in the whole-stream perturbations also support expectations from the small-scale experiment that Glossosoma has negative effects on their abundances. However, the observation of large-scale perturbations was essential to better understand the full extent and magnitude of Glossosoma's effects in the community.

Compared to competitors and predators, the role of parasites in ecological communities has received little study (Anderson and May 1986, Dobson and Hudson 1986, Minchella and Scott 1991, Dobson and Crawley 1994). Theoretical arguments suggest that parasites should often have strong impacts in simple food webs in which density-dependent dynamics are important (Holt and Pickering 1985, Anderson and May 1986, Grenfell 1992). Observed changes in species' abundances and diversity following the invasion of a pathogen (or host) into established communities provide some empirical support for the models (Anderson and May 1986, Dobson and Hudson 1986, Dobson and Crawley 1994). Because Cougourdella in our study systems is host specific and highly virulent, it acts as a keystone parasite (sensu Paine 1966) through its effects on a competitive dominant, Glossosoma. Many other microparasites exhibit similar characteristics and can suppress population densities of their hosts (Anderson and May 1981, Briggs et al. 1995). This suggests that pathogens may frequently be strong interactors in food webs. This mechanism is only one of several by which parasites can effect community structure (Anderson and May 1986, Holmes and Price 1986, Minchella and Scott 1991). Clearly, any model of community structure that does not consider the potential importance of parasites may be woefully incomplete (Sousa 1991), and increased empirical attention to interactions involving parasites in food webs is needed.

Our observations suggest that the dynamics of stream communities may be strongly affected by both long-term host-parasite dynamics and competition. If, as is expected for many microparasites of invertebrates, the host-parasite interaction produces cyclic or chaotic population dynamics in the host (Anderson and May 1981, May 1985a) and/or host and parasite are engaged in a long-term coevolutionary relationship (May $1985 b$ ), then communities strongly influenced by the host may exhibit highly variable configurations. Such changes in community structure driven by the hostparasite interaction appear to be occurring in Hunt Creek, where the Glossosoma population has experienced two sequential periods of dominance and subsequent collapse over the past $15 \mathrm{yr}$. Thus, in these stream communities host-parasite interactions may promote a highly dynamic community structure more typically associated with high rates of physical (e.g., hydrologic) disturbance (Horwitz 1978, Huston 1979, Ross et al. 1985, Death and Winterbourn 1994).

In addition to questions regarding the scale(s) at which to conduct experiments, ecologists studying organisms with complex life cycles must also consider which life history stage(s) to study to understand the processes affecting population dynamics and community structure. For many freshwater animals having aquatic immatures and terrestrial adults (e.g., many insects and amphibians), it is often assumed that processes acting on the larval stage are particularly important in determining population dynamics (Wilbur 
1988). Our results strongly support this assumption. Field and laboratory experiments have identified mechanisms of important interactions affecting larval performance (Wiley and Kohler 1981, McAuliffe 1984, Hart 1987, Kohler 1992), and the pathogen outbreaks illustrate the population- and community-level consequences of such processes. The strength of the link between interactions in the larval stage and long-term population dynamics may be a function of attributes of the systems we have studied. First, the taxa we have studied have short-lived adults, and adult fecundity and size are established during larval development, so that processes affecting larval performance should readily translate to effects on adult reproductive success. The link between larval performance and adult fitness may be weaker in taxa with longer-lived adults (Peckarsky et al., in press). Second, the highly stable flow regimes of the groundwater-driven systems we have investigated (Wiley et al. 1997) contrast sharply with the more variable flow regimes characteristic of many streams (Poff and Ward 1989). Peckarsky et al. (in press) suggest that the long-term dynamics of invertebrates in less hydrologically stable streams may be determined largely by flow-related disturbances, even when interactions among larvae are strong within generations.

In conclusion, our results emphasize both the utility of small-scale experiments and the value of long-term experiments conducted over broad spatial scales. The small-scale experiment successfully predicted many of the competitive effects observed over larger scales, but studies at larger temporal and spatial scales were necessary to accurately quantify the population- and community-level effects of species interactions in these systems.

\section{ACKNOWLEDGMENTS}

We thank the numerous individuals who have assisted in the field and lab, especially Katie Busse, Deb Corti, Kay Edly, Chuck Elzinga, Neal Godby, Katie Hallat, Roger Haro, Jeff Heilveil, Leon Hinz, Wade Hoiland, Mike Hoppenworth, Melinda Knapp, Anne Monnelly, Suzanne Nelson, Laurel Nida, Mike Slamecka, Amy Sosin, Randy Spaller, and Dave Zaber. We are grateful to Gaylord Alexander and Andy Nuhfer for hospitality and cooperation at Hunt Creek. Scott Cooper, Carol Folt, Dave Hart, Bill Resetarits, Göran Englund, Mark McPeek, and an anonymous reviewer offered helpful suggestions on previous versions of the manuscript. This work has been supported by NSF grants BSR-8717662, DEB9119668, and DEB-9120686.

\section{Literature Cited}

Anderson, R. M., and R. M. May. 1981. The population dynamics of microparasites and their invertebrate hosts. Philosophical Transactions of the Royal Society of London, Series B 291:451-524.

Anderson, R. M., and R. M. May. 1986. The invasion, persistence and spread of infectious diseases within animal and plant communities. Philosophical Transactions of the Royal Society of London, Series B 314:533-570.

Bender, E. A., T. J. Case, and M. E. Gilpin. 1984. Perturbation experiments in community ecology: theory and practice. Ecology 65:1-13.

Briggs, C. J., R. S. Hails, N. D. Barlow, and H. C. J. Godfray.
1995. The dynamics of insect-pathogen interactions. Pages 295-326 in B. T. Grenfell and A. P. Dobson, editors. Ecology of infectious diseases in natural populations. Cambridge University Press, New York, New York, USA.

Brown, J. H., D. W. Davidson, J. C. Munger, and R. S. Inouye. 1986. Experimental community ecology: the desert granivore system. Pages 41-61 in J. Diamond and T. J. Case, editors. Community ecology. Harper and Row, New York, New York, USA.

Carignan, R., and D. Planas. 1994. Recognition of nutrient and light limitation in turbid mixed layers: three approaches compared in the Parana floodplain (Argentina). Limnology and Oceanography 39:580-596.

Carpenter, S. R., and J. F. Kitchell. 1988. Consumer control of lake productivity. BioScience 38:764-769.

Connell, J. H. 1983. On the prevalence and relative importance of interspecific competition: evidence from field experiments. American Naturalist 122:661-696.

Cooper, S. D., S. Diehl, K. Kratz, and O. Sarnelle. In press. Implications of scale for patterns and process in stream ecology. Australian Journal of Ecology.

Dayton, P. K., and M. J. Tegner. 1984. The importance of scale in community ecology: a kelp forest example with terrestrial analogs. Pages $457-481$ in P. W. Price, C. N. Slobodchikoff, and W. S. Gaud, editors. A new ecology: novel approaches to interactive systems. John Wiley and Sons, New York, New York, USA.

Death, R. G., and M. J. Winterbourn. 1994. Environmental stability and community persistence: a multivariate perspective. Journal of the North American Benthological Society 13:125-139.

Dobson, A., and M. Crawley. 1994. Pathogens and the structure of plant communities. Trends in Ecology and Evolution 9:393-398.

Dobson, A. P., and P. J. Hudson. 1986. Parasites, disease and the structure of ecological communities. Trends in Ecology and Evolution 1:11-15.

Englund, G., and T. Olsson. 1996. Treatment effects in a stream fish enclosure experiment: influence of predation rate and prey movements. Oikos 77:519-528.

Frost, T. M., D. L. DeAngelis, S. M. Bartell, D. J. Hall, and S. H. Hurlbert. 1988. Scale in the design and interpretation of aquatic community research. Pages $229-258$ in S. R. Carpenter, editor. Complex interactions in lake communities. Springer-Verlag, New York, New York, USA.

Gascon, C., and J. Travis. 1992. Does the spatial scale of experimentation matter? A test with tadpoles and dragonflies. Ecology 73:2237-2243.

Goldberg, D. E., and A. M. Barton. 1992. Patterns and consequences of interspecific competition in natural communities: a review of field experiments with plants. American Naturalist 139:771-801.

Grenfell, B. R. 1992. Parasitism and the dynamics of ungulate grazing systems. American Naturalist 139:907-929.

Gurevitch, J., L. L. Morrow, A. Wallace, and J. S. Walsh. 1992. A meta-analysis of competition in field experiments. American Naturalist 140:539-572.

Hart, D. D. 1987. Experimental studies of exploitative competition in a grazing stream insect. Oecologia (Berlin) 73: 41-47.

Hart, D. D., S. L. Kohler, and R. G. Carlton. 1991. Harvesting of benthic algae by territorial grazers: the potential for prudent predation. Oikos 60:329-335.

Hart, D. D., and C. T. Robinson. 1990. Resource limitation in a stream community: effects of phosphorus enrichment on periphyton and grazers. Ecology 71:1494-1502.

Holmes, J. C., and P. W. Price. 1986. Communities of parasites. Pages 187-213 in J. Kikkawa and D. J. Anderson, editors. Community ecology: pattern and process. Blackwell Scientific, Oxford, UK. 
Holt, R. D., and J. Pickering. 1985. Infectious disease and species coexistence: a model of Lotka-Volterra form. American Naturalist 126:196-211.

Horwitz, R. J. 1978. Temporal variability patterns and the distributional patterns of stream fishes. Ecological Monographs 48:307-321.

Huston, M. 1979. A general hypothesis of species diversity. American Naturalist 113:81-101.

Ives, A. R., P. Kareiva, and R. Perry. 1993. Response of a predator to variation in prey density at three hierarchical scales: lady beetles feeding on aphids. Ecology 74:19291938.

Kohler, S. L. 1992. Competition and the structure of a benthic stream community. Ecological Monographs 62:165-188.

Kohler, S. L., and M. J. Wiley. 1992. Parasite-induced collapse of populations of a dominant grazer in Michigan streams. Oikos 65:443-449.

Kovalak, W. P. $1978 a$. Relationships between size of stream insects and current velocity. Canadian Journal of Zoology 56: $178-186$

1978b. Effects of a pool on stream invertebrate drift. American Midland Naturalist 99:119-127.

Lawlor, L. R. 1979. Direct and indirect effects of n-species competition. Oecologia 43:355-364.

Leibold, M. A., and H. M. Wilbur. 1992. Interactions between food-web structure and nutrients on pond organisms. Nature 360:341-343.

Levin, S. A. 1992. The problem of pattern and scale in ecology. Ecology 73:1943-1967.

Lively, C. M., P. T. Raimondi, and L. F. Delph. 1993. Intertidal community structure: space-time interactions in the northern Gulf of California. Ecology 74:162-173.

MacArthur, R. H. 1972. Geographical ecology. Harper and Row, New York, New York, USA.

May, R. M. 1985a. Regulation of populations with nonoverlapping generations by microparasites: a purely chaotic system. American Naturalist 125:573-584.

. 1985b. Host-parasite associations: their population biology and population genetics. Pages 243-262 in D. Rollinson and R. M. Anderson, editors. Ecology and genetics of host-parasite interactions. Academic Press, Orlando, Florida, USA.

McAuliffe, J. R. 1984. Resource depression by a stream herbivore: effects on distributions and abundances of other grazers. Oikos 42:327-333.

Minchella, D. J., and M. E. Scott. 1991. Parasitism: a cryptic determinant of animal community structure. Trends in Ecology and Evolution 6:250-254.

Neill, W. E. 1994. Spatial and temporal scaling and the organization of limnetic communities. Pages 189-231 in P. S. Giller, A. G. Hildrew, and D. G. Raffaelli, editors. Aquatic ecology: scale, pattern and process. Blackwell Scientific, London, UK.

Paine, R. T. 1966. Food web complexity and species diversity. American Naturalist 100:65-75.

. 1980. Food webs: linkage, interaction strength and community infrastructure. Journal of Animal Ecology 49: $667-685$.

Peckarsky, B. L., S. D. Cooper, and A. R. McIntosh. In press. Extrapolating from scales of individual behavior to populations and communities in streams. Journal of the North American Benthological Society.
Peterson, B. J., J. E. Hobbie, A. E. Hershey, M. A. Lock, T. E. Ford, J. R. Vestal, V. L. McKinley, M. A. J. Hullar, M. C. Miller, R. M. Ventullo, and G. S. Volk. 1985. Transformation of a tundra river from heterotrophy to autotrophy by addition of phosphorus. Science 229:1383-1386.

Pimm, S. L. 1991. The balance of nature? University of Chicago Press, Chicago, Illinois, USA.

Poff, N. L., and J. V. Ward. 1989. Implications of streamflow variability and predictability for lotic community structure: a regional analysis of streamflow patterns. Canadian Journal of Fisheries and Aquatic Sciences 46:1805-1818.

Ross, S. T., W. J. Matthews, and A. A. Echelle. 1985. Persistence of stream fish assemblages: effects of environmental change. American Naturalist 126:24-40.

Sarnelle, O. 1997. Daphnia effects on microzooplankton: comparisons of enclosure and whole-lake responses. Ecology 78:913-928.

Schindler, D. W., K. H. Mills, D. F. Malley, D. L. Findlay, J. A. Schearer, I. J. Davies, M. A. Turner, G. A. Linsey, and D. R. Cruikshank. 1985. Long-term ecosystem stress: the effects of years of experimental acidification on a small lake. Science 228:1395-1401.

Schoener, T. W. 1983. Field experiments on interspecific competition. American Naturalist 122:240-285.

Sih, A., P. Crowley, M. McPeek, J. Petranka, and K. Strohmeier. 1985. Predation, competition, and prey communities: a review of field experiments. Annual Review of Ecology and Systematics 16:269-311.

Sokal, R. R., and F. J. Rohlf. 1981. Biometry. W. H. Freeman, New York, New York, USA.

Sousa, W. P. 1991. Can models of soft-sediment community structure be complete without parasites? American Zoologist 31:821-830.

Tilman, D. 1989. Ecological experimentation: strengths and conceptual problems. Pages 136-157 in G. E. Likens, editor. Long-term studies in ecology: approaches and alternatives. Springer-Verlag, New York, New York, USA.

Wiens, J. A., J. F. Addicott, T. J. Case, and J. Diamond. 1986. Overview: the importance of spatial and temporal scale in ecological investigations. Pages 145-153 in J. Diamond and T. J. Case, editors. Community ecology. Harper and Row, New York, New York, USA.

Wilbur, H. M. 1988. Interactions between growing predators and growing prey. Pages 157-172 in B. Ebenman and L. Persson, editors. Size-structured populations. SpringerVerlag, Berlin, Germany.

Wiley, M. J., and S. L. Kohler. 1981. An assessment of biological interactions in an epilithic stream community using time-lapse cinematography. Hydrobiologia 78:183188.

Wiley, M. J., S. L. Kohler, and P. W. Seelbach. 1997. Reconciling landscape and site based views of aquatic communities: lessons from Michigan trout streams. Freshwater Biology 37:133-148.

Williamson, C. E. 1993. Linking predation risk models with behavioral mechanisms: identifying population bottlenecks. Ecology 74:320-331.

Wootton, J. T. 1992. Indirect effects, prey susceptibility, and habitat selection: impacts of birds on limpets and algae. Ecology 73:981-991.

- 1994. Predicting direct and indirect effects: an integrated approach using experiments and path analysis. Ecology 75:151-165. 